\title{
LABELING OPTIONS FOR POSTAL SHIPMENTS BY PASSIVE RFID TECHNOLOGY
}

\author{
Ondrej Maslák ${ }^{1}$, Ivana Andrisková ${ }^{2}$
}

\begin{abstract}
This article discusses the topic of labeling postal shipments by passive radio frequency identification (RFID) tags. Every delivery company needs to have all necessary information for every single postal shipment package it carries. Shipment package labeling is essential for processing and tracking the postal shipments along its delivery process. Using RFID technology for the process brings advantages in more efficient delivery and data collection along with regular information updates of shipment status across complete delivery chain.

In this article, we focused on the problem of logical log of key shipment package information into EPC memory of the RFID smart label. We have taken into account the National postal administrator and its current system of shipment labeling. In the end, we presented a design for conversion of contemporary labeling using bar codes into labeling using RFID tags.
\end{abstract}

JEL Classification Numbers: L87, DOI: http://dx.doi.org/10.12955/cbup.v3.641

Keywords: RFID, postal, labeling, EPC

\section{Introduction}

Manual data collection, which includes reading data and manual data recording, is a process in which a human can make a mistake. However, automation process can reduce human errors to minimum, and the main advantage for its implementing is faster speed. A possibility for accelerating data collection process may seem to be a key reason for the use of automatic identification, which can be seen in various forms, e.g. one dimensional bar codes or Radio Frequency IDentification technology (RFID technology). One dimensional bar codes, which are the most popular, are used for identifying goods in almost every data collection process. Bar code is an automatic identifier composed of combination of lines and empty areas between lines with sufficient contrast (Palmer, 2007). Nowadays, two mentioned technologies are often being utilized in combination, while each has its specific advantages.

\section{RFID technology}

RFID technology is based on wireless radio frequency communication and identification. Radio frequencies for RFID are a part of spectrum commons - unlicensed spectrum (Milgrom, Levine, \& Eilat, 2011). This implies that there is an open access to frequencies according to international harmonization (ERC REC, 2011). Simple and effective frequency identification found its place in the area of automatic identification along with technology of bar codes. Technologies of automatic identification include each technology where there is no need for humans in the process of data collection or technologies, and where a part of the process is automated (Rouse, 2010).

The role of RFID is not supposed to be in replacing bar code technology. The basic elements of RFID technology include a label and an RFID reader. Label is attached to goods, estate, or room; reader obtains data logged in the label memory. Then, the process is followed by reader communication with system and sending loaded data to a server, e.g. RFID middleware server. Middleware is a software, a connection between hardware and other applications (Glover \& Bhatt, 2006).

There are two types of RFID tags: active and passive. Passive tags are well known for their lower expense in comparison to the active tags. The lower expense is a result of having lower capabilities and no internal battery requirement. Passive tags do not contain a power source. To power the tag

\footnotetext{
1 Ing. Ondrej Maslák, University of Žilina in Žilina, FPEDaS, Department of Communication, ondrej.maslak@fpedas.uniza.sk

2 Ing. Ivana Andrisková, University of Žilina in Žilina, FPEDaS, Department of Communication, ivana.andriskova@fpedas.uniza.sk
} 
circuitry, the tag relies on electromagnetic power obtained from the RFID system antenna (Jones \& Chung, 2008).

In contrast to passive RFID tags, active RFID tags have an integrated power source, which usually uses small batteries to supply the circuitry and to generate the response data. As the active tag requires an extra battery, the size of the active tag is larger, and the production cost will be higher (Chan \& Baciu, 2012). For this reason, active tags are currently only being utilized in applications where active tags' enhanced capabilities can be taken advantage of and are not suitable for labeling staple goods (Jones \& Chung, 2008).

\begin{tabular}{|l|l|}
\hline Figure 1: Passive RFID tag \\
\hline Source: Glover, Bhatt (2006) \\
\hline
\end{tabular}

RFID systems can be very complex. For the purposes of discussion in this article, an RFID system is composed of up to three subsystems:

- an RF subsystem performs identification and related transactions using wireless communication;

- an enterprise subsystem contains computers running specialized software that can store, process, and analyze data acquired from RF subsystem transactions to make the data useful to a supported business process;

- an inter-enterprise subsystem connects enterprise subsystems when information needs to be shared across organizational boundaries (Tipton \& Nozaki, 2011).

RFID memory tag is structured into four sections, the so called banks:

- Bank 00 - reserved: contains access information for passwords;

- Bank 01 - contains Electronic Product Code $^{3}$ (further EPC), plus filter value and protocol control bits;

- Bank 10 - contains Tag Identification bits (further TID), which provide information about the rag itself, as opposed to the physical object to which the tag is fixed;

- Bank 11 - user: contains business data (GS1 EPC, 2011).

\section{Current system of labeling the shipment units utilized by National postal administrator}

In Slovakia, National postal administrator is referred to as "Slovenská pošta" (SP). SP has been operating in the postal services market for over 15 years already (Slovenská pošta, 2015). The shipments at SP offices are being labeled by one dimensional bar code 128 , which has the ability to represent alphanumeric characters (Pantanowitz \& Tuthill, 2012; Technické parametre - Označovanie zásielok, 2015). Bar code consists of 13 alphanumeric characters, which represent a full delivery number, including a control digit. The first 2 characters are reserved for the service code. They are followed by 8 characters, which represent detailed information about the shipment unit. Every character can be changed depending on the shipment characteristics.

\footnotetext{
${ }^{3}$ The Electronic Product code is a globally unique identifier for the physical object to which the tag is affixed.
} 
Bar code "CODE128" can be found in three different versions. Basic type "CODE128 A" supports alphanumeric characters (numbers, upper-case letters, and control characters). Type "CODE128 B" is able to represent numbers, upper and lower-case letters. The last type "CODE128 C" supports up to 19 characters, which can be represented by numbers only (Palmer, 2007). Since SP uses upper-case letters only for shipment labeling, the subtype "CODE128 A" is suitable choice.

When the shipment is handed in for delivery at post office, it is labeled by a ticket, which consists of bar code and basic shipment information. This is essential for creating information flow. The information is updated in the direction of physical delivery flow of a particular shipment. In the process of delivery chain, the shipment moves along a physical flow from point A to point B. Between these two points, there can be more points (offices) where a shipment can be scanned in order to be traced, checked, and updated of its status. Every shipment has its virtual record saved in the database. Access is possible after full delivery number is entered. SP also offers a service of electronic filling form via the postal website. This service is available for individuals and legal entities those are registered as SP partners; they have their own range of full delivery numbers, which is of greater convenience when hundreds of shipments are sent each week (Technické parametre - ePodací hárok, 2014).

\section{The labelling system using RFID technology}

The designed labelling system using RFID technology in the delivery process could be utilized for several elements, respectively:

- shipments unit - parcel or letter,

- shipping and handling units,

- transport courses,

- objects, nodes, and delivery posts.

\begin{tabular}{|l} 
Figure 2: A possible design for labeling the delivery chain elements by RFID \\
$\begin{array}{c}\text { Labeling of transport unit } \\
\text { for final checking and } \\
\text { management of transport unit } \\
\text { (passive RFID) }\end{array}$ \\
$\begin{array}{l}\text { Labeling of single } \\
\text { shipment package } \\
\text { (passive RFID tag) }\end{array}$
\end{tabular}

\section{Logical structure of EPC memory}

After selecting a suitable RFID tag (Maslák, 2014) and testing of passive RFID technology for labeling the shipments (Maslák, Tengler, \& Vaculík. 2014), as we did in our previous work, there arises a need for creating a logical label structure. Every label has to contain information about the 
object to which it is attached-in our case it is a parcel ${ }^{4}$. In order to be able to label the parcels equally we need to create a method for data structuring, data logging into RFID tag and coding and decoding. Tag logical structure is easily to design when we answer following questions:

- What kind of data are to be saved into the tag?

- In what kind of data format is to be saved into the tag?

- How to obtain the data saved in the tag?

Each RFID tag has its own inner structure, which can be divided into three parts:

- EPC memory,

- user memory,

- access and kill passwords.

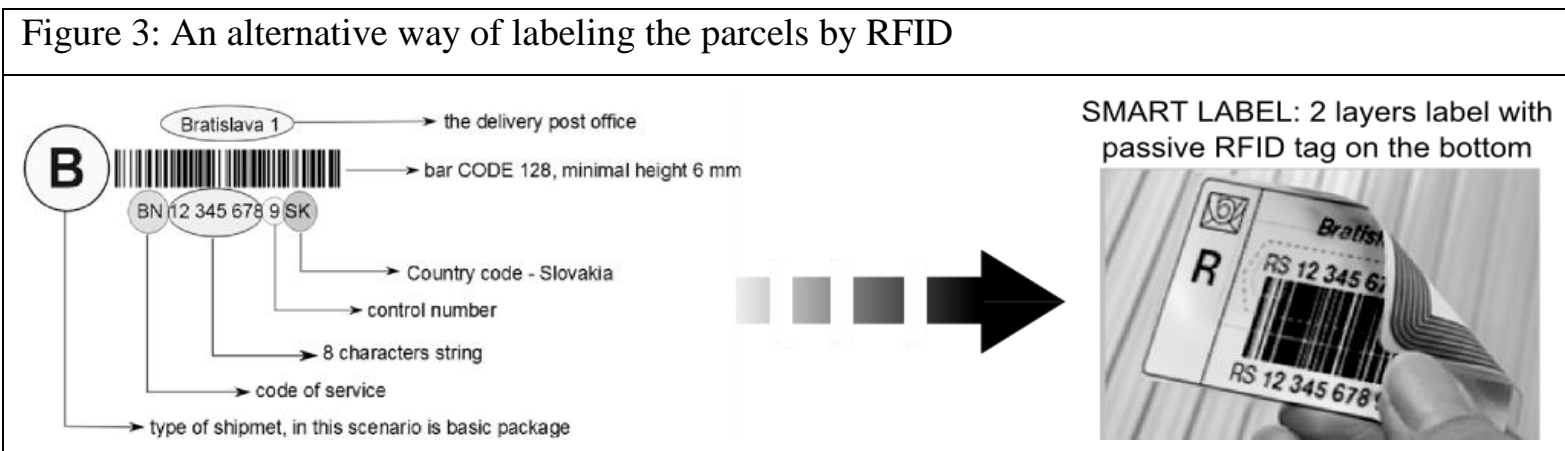

Source: Authors

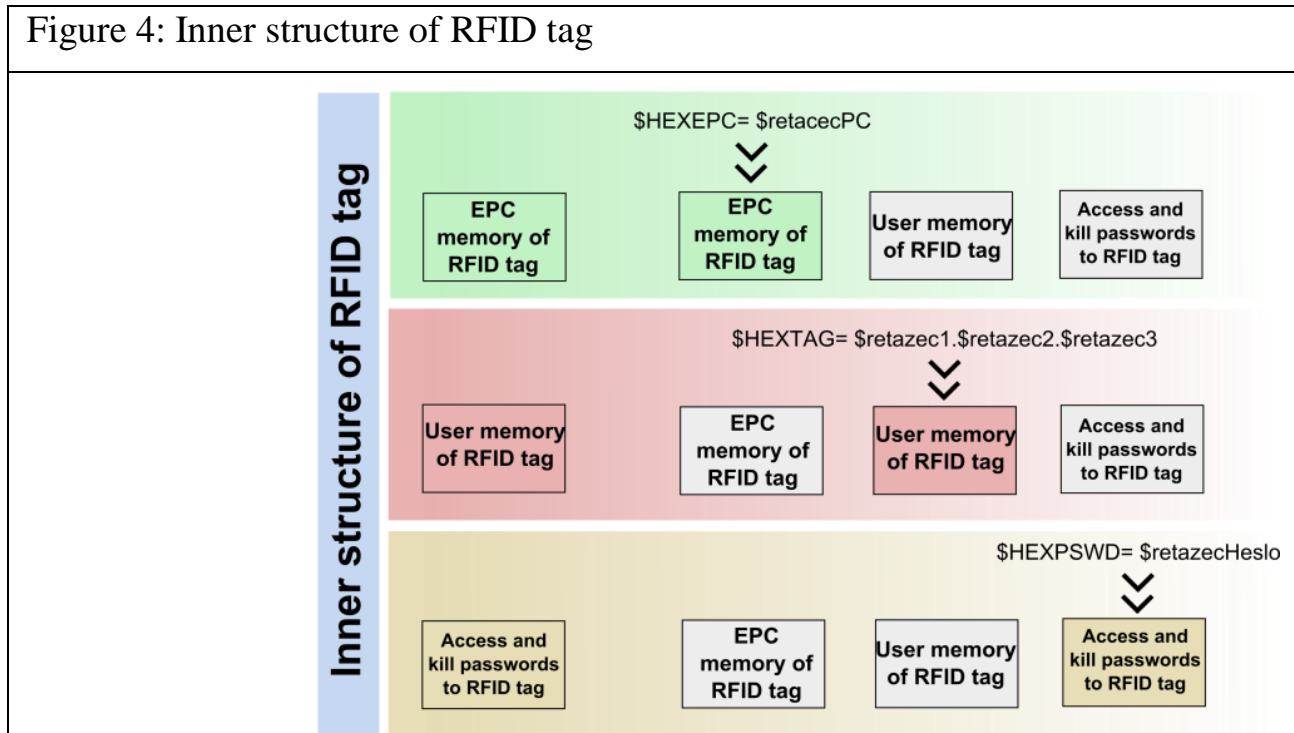

Source: Authors

In this article, we discuss the design of the first part of RFID inner structure, namely EPC memory, which is shown in Figure 4. \$HEXEPC will contain destination string (binary-digit string) in hexadecimal form, which should be logged into EPC memory. Structured data of this variable \$retacecPC is described in detailed form in Table 1.

${ }^{4}$ we selected parcels since testing passive RFID technology for labeling letters was already accomplished in the work of Zelik (2010). 


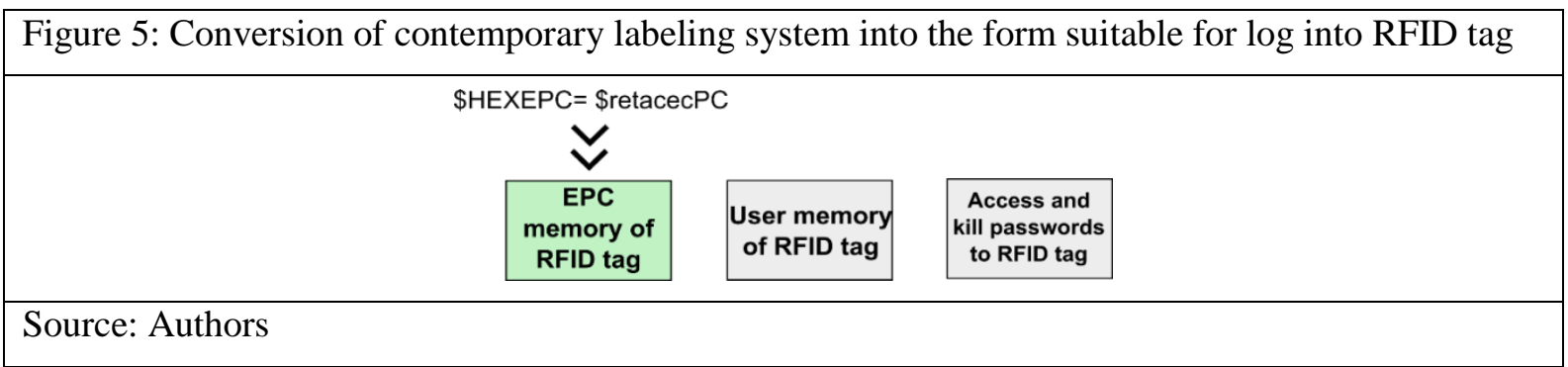

\section{Logical log of key shipment package information into EPC memory}

Selected type of RFID tag has 96 bits available in EPC memory, 512 bits in user memory, 32 bits for access password, and 32 bits for kill password. Nowadays, there is a wide range of passive RFID tags with different versions of internal memory. EPC memory size of 96 bits is standard, but there are also higher-bit memories. User memory is not supposed to be more than 512 bits, but in case of special requirements there are tags up to $4-8$ kilobytes more. Memory size has a significant impact on RFID tag price. We take this fact into consideration and attempt to reduce data when logging into EPC memory of an RFID tag.

Our design is realized by subdividing a full delivery number into three parts (Figure 6), while each one will be coded by some other method. First two characters will be encoded by the function string to hexadecimal form, and this approach will also be used when encoding the third part-country code. This method is especially suitable if we encode alphanumeric characters, where 8 bits is reserved for each character. If we used this method for encoding the second part of delivery number-reference number and checking digit (altogether 9 characters; control digit has the number form as well), we would need $9 * 8$ or 72 bits. Taking into account 96 bits of EPC memory, there would only be 24 bits left. These remaining bits are not enough to meet the memory requirements of the first part of the service code (16 bits) and country code (16 bits) - 32 bits in 8-bit ASCII form. Since the reference number + checking digit contain numbers only, we can apply encoding method of decimal number to hexadecimal number. For a longer sequence of numbers, it is always more appropriate. 32 bits is the maximum limit for any combination of 9 numbers (our case).

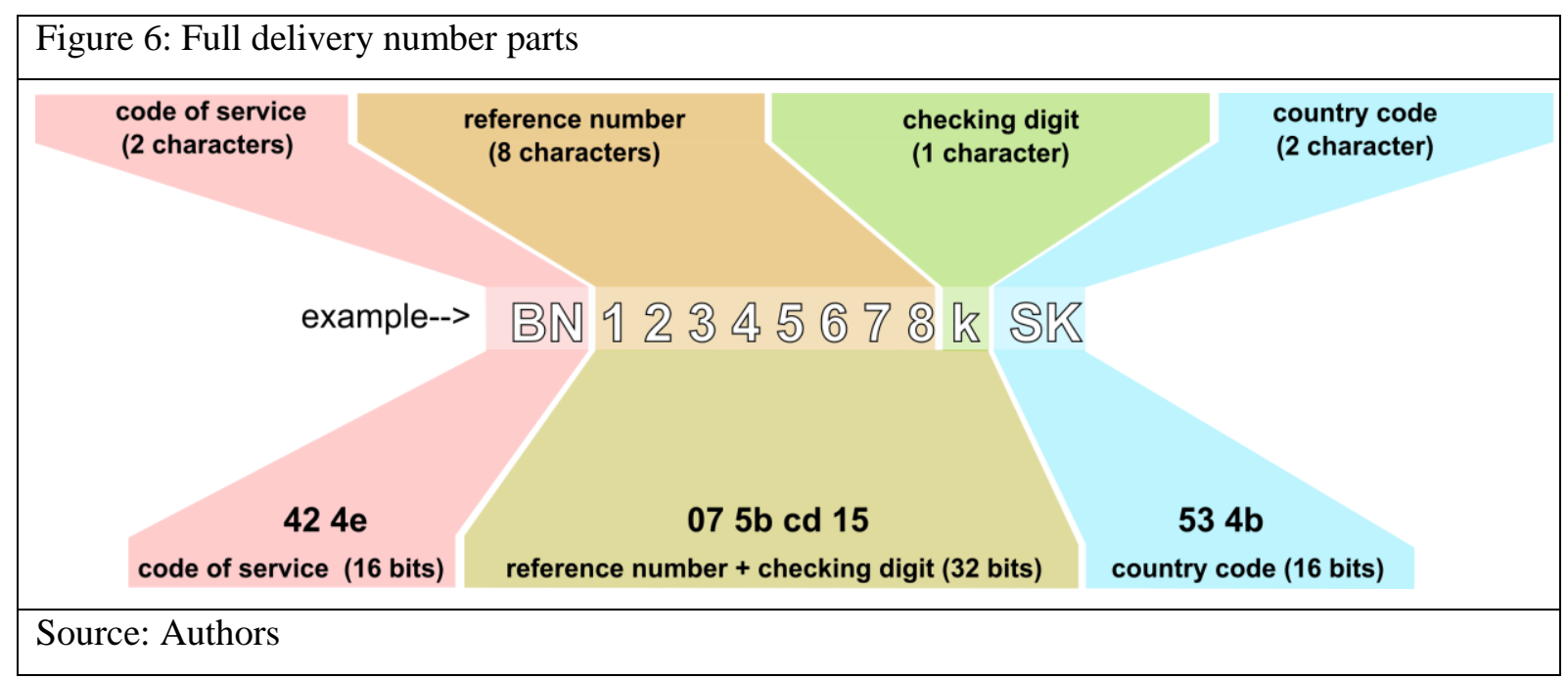

Transcription of reference number from hexadecimal form to lowest binary level, for example: $(075 \mathrm{bcd} 15)_{16}=(00000111010110111100110100010101)_{2}$.

The size of each part is fixed; therefore, we know the exact point where the first part (code of service) ends and where the second one (reference number + checking digit) and the third one (country code) begin. In the variable \$HEXEPC, there numbers will be saved in hexadecimal form that is suitable for 
$\log$ into RFID tag. The string logged into RFID can be clearly subdivided into three parts. By using an appropriate method, it is possible to convert it back to alphanumeric characters, and the result will be merged into the original string.

\begin{tabular}{|c|c|c|c|}
\hline \multicolumn{3}{|c|}{ Table 1: Coding table } \\
\hline Scheme & \multicolumn{3}{|c|}{ Postal EPC memory } \\
\hline Total size in bits & \multicolumn{3}{|c|}{ retacezPC } \\
\hline Mask & 16 & Reference number & Country code \\
\hline Logical scheme & Code of service & 16 \\
\hline $\begin{array}{c}\text { Logical segment } \\
\text { size in bits }\end{array}$ & $\mathrm{b}_{63}-\mathrm{b}_{48}$ & 32 & $\mathrm{~b}_{15}-\mathrm{b}_{0}$ \\
\hline Bit position & $\begin{array}{c}\text { String to } \\
\text { hexadecimal } \\
\text { (ASCII 8bit for } \\
\text { each character) }\end{array}$ & $\begin{array}{c}\text { Integer number to } \\
\text { hexadecimal (32 bits) }\end{array}$ & $\begin{array}{c}\text { String to hexadecimal } \\
\text { (ASCII 8bit for each } \\
\text { character) }\end{array}$ \\
\hline Coding Method
\end{tabular}

Source: Authors

Table 2: Coding table

\begin{tabular}{|c|l|}
\hline Logical scheme & \multicolumn{1}{c|}{ Content } \\
\hline Code of service & $\begin{array}{l}\text { 2-digit alphanumerical string (according to current } \\
\text { labeling system) }\end{array}$ \\
\hline Reference number & $\begin{array}{l}\text { 8-digit integer number + checking digit according } \\
\text { current labeling. (9- digit integer number) }\end{array}$ \\
\hline Country code & 2-digit alphanumerical string of country labeling \\
\hline
\end{tabular}

Source: Authors

\section{Conclusion}

The final design of labeling is materialized in the form of intelligent RFID tag. The tag is composed of two physical layers, while the upper layer, paper, may be the same form the SP uses now for labeling shipment units. The second layer, RFID tag, is programmed according to specific needs. Logical log of key shipment package information into EPC memory of RFID smart label and printing the upper layer may be done simultaneously in one step, or the bottom layer may be logged later. It is also possible to change or to log additional information into the EPC memory during the physical process of delivery, or even during processing at offices. Data updating is also possible offline without connection to the central database (a possibility of logging the time of processing, etc.). When the entry of shipment is created, via electronic filling form, all necessary data are saved into system; paper label is generated and may be printed. The current SP platform system of labeling can be utilized to obtain all necessary data for RFID tag, thus there is no need to design a new platform.

Business processes efficiency and its benefits can be divided into two basic groups:

- marketing benefits - support for new services, added value for final customers;

- operational benefits - shortened process time, shipments monitoring.

Utilization of labeling the shipments using passive RFID can be expected by following benefits:

- designed solution helps to make post and delivery process more effective; 
- quality improvement, finding network bottlenecks;

- tracking without the need of optical visibility while scanning;

- multiple shipments control;

- better traceability of shipments;

- Shipment units control on entry and exit;

- cost reduction.

\section{Acknowledgements}

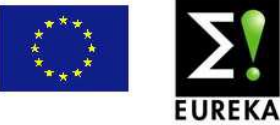

E!7592 AUTOEPCIS - RFID Technology in Logistic Networks of Automotive Industry (RFID technológie v logistických sietach automobilového priemyslu) Za podpory Ministerstva školstva, vedy, výskumu a športu.

VEGA 1/0515/15 Endogenous factors of the IPR intensive Industries in the regional enterprise environment in Slovak Republic

\section{References}

Chan, E., \& Baciu, G. (2012). Active RFID tag. Introduction to wireless localization with iPhone SDK examples. Hoboken, N.J.: Wiley

ERC Recommendation 70-03 [ERC REC] (2001). ERC Recommendation 70-03 (Tromsø 1997 and subsequent amendments). Relating to the Use of Short Range Devices (SRD). Recommendation Adopted by the Frequency Management, Regulatory Affairs and Spectrum Engineering Working Groups. Retrieved March 29, 2015, from http://www.ecodocdb.dk/Docs/doc98/official/word/Rec7003e.doc

Glover, B., \& Bhatt, H. (2006). Readers and printers. RFID essentials. Sebastopol, CA: O'Reilly.

GS1 EPC Tag Data Standard 1.6. (2011, September). Retrieved March 29, 2015, from http://www.gs1.org/gsmp/kc/epcglobal/tds/tds_1_6-RatifiedStd-20110922.pdf

Jones, E., \& Chung, C. (2008). Passive tags. In RFID in logistics: A practical introduction. Boca Raton: CRC Press.

Maslák, O. (2014). Použitel'nost' pasívnej RFID technológie pri spracovaní balíkov [Usability of passive RFID technology in package processing]. Vedecký časopis študentov Doktorandského štúdia Fakulty Prevádzky a Ekonomiky Dopravy a Spojov Žilinskej Univerzity v Žiline, 2(2).

Maslák, O., Tengler, J., \& Vaculík, J. (2014). Označovanie poštových zásielok pomocou technológie rádiofrekvenčnej identifikácie [Labeling of postal service using radio frequency identification technology]. Diagnostika Podniku, Controlling a Logistika.

Milgrom, P., Levine, J., \& Eilat, A. (2011, October). The Case for Unlicensed Spectrum. Retrieved March 29, 2015, from http://dx.doi.org/10.2139/ssrn.1948257

Palmer, R. (2007). The bar code book: A comprehensive guide to reading, printing, specifying, evaluating and using bar code and other machine-readable symbols (5th ed.). Victoria, B.C.: Trafford

Pantanowitz, L., \& Tuthill, J. (2012). Pathology informatics: Theory \& practice. Chicago, IL: American Society for Clinical Pathology Press.

Rouse, M. (2010, November). Automatic Identification and Data Capture (AIDC). Retrieved from http://searchmanufacturingerp.techtarget.com/definition/Automatic-Identification-and-Data-Capture-AIDC

Slovenská pošta - information (n.d.). Retrieved March 29, 2015, from http://www.posta.sk/en/information/information

Technické parametre - Označovanie zásielok. (2015, January). Retrieved March 29, 2015, from http://www.posta.sk/subory/36947/technicke-parametre-oznacovanie-zasielok.pdf

Technické parametre - ePodací hárok. (2014, April). Retrieved from https://mojezasielky.posta.sk/public/manuals/technickeparametre-epodaci-harok-platne-od-042014.pdf

Tipton, H., \& Nozaki, M. (2011). Technology. Information Security Management Handbook (6th ed.). Hoboken: CRC Press. 